\title{
Impact of Poverty on Housing Condition in Gwagwalada Urban Area of Federal Capital Territory (FCT) of Abuja
}

\author{
Ebehikhalu O. Nicholas ${ }^{1} \&$ Dawam D. Patrick ${ }^{1}$ \\ ${ }^{1}$ Department of Geography and Environmental Management, University of Abuja, FCT Abuja, Nigeria. \\ Correspondence: Ebehikhalu O. Nicholas, Department of Geography and Environmental Management, University of \\ Abuja, FCT Abuja, Nigeria.
}

Received: May 15, 2015

Accepted: May 29, 2015

Available online: July 21, 2015

doi:10.11114/ijsss.v3i5.961

URL: http://dx.doi.org/10.11114/ijsss.v3i5.961

\begin{abstract}
This study examines the impact of poverty on housing in the urban area of Gwagwalada of the FCT, Abuja. The data for the study were derived from both primary and secondary sources. Primary data were derived mainly from the administration of questionnaire. Stratified random sampling technique was used to administer the questionnaire to the respondents in the study area based on the income of the respondents expressed as high, middle and low income area. A total of six hundred (600) questionnaire were administered in the study area of which one hundred (100) questionnaire were administered in the high income area, two hundred (200) questionnaire were administered to middle income area while three hundred (300) questionnaire were administered to low income area. The data were analyzed using both descriptive and simple inferential statistics. The findings revealed that poverty has a lot of negative impacts on the housing condition in the study area. This find expression in the fact that majority of the respondents have not been able to maintain their houses and live close to their work places. As a result of the fact that more people live in the low income area, a lot of pressure are exerted on the few available facilities. The study suggested some possible measures of addressing the housing poverty in the study area.
\end{abstract}

Keywords: Housing, Poverty and Rural-Urban Fringe

\section{Introduction}

Nigeria exemplifies the paradox of rich nation populated by poor people. Poverty as a public policy concern, whether at the global, national or community level, is now widely considered to be a multidimensional problem. Studies of the problems of poor people and communities, and of the obstacles and opportunities to improving their situation, have led to an understanding of poverty as a complex set of deprivations (Fukuda-Parr, 2006). Poverty is the condition that is said to exist when the people lack the means to satisfy their needs. The World Bank (1999), describes poverty as hunger, lack of shelter; being sick and not being able to go to school; not knowing how to read; not being able speak properly; not having a job; fear for the future; losing a child to illness brought about by unclean water; powerlessness; and lack of representation and freedom. Aluko (2001) has argued that for most Nigeria, poverty is endemic, is real and devastating. For large percentage of the population there is no food, housing and health security. Life in Nigeria involves a daily struggle against hunger and a total lack of housing and health facilities. There is no social welfare network to ameliorate the condition of the poor. The poor in Nigeria depend largely and mostly on relations and friends for a bit of sustenance. Poverty in its entire ramification is antithetical to development. Therefore we cannot meaningfully talk about housing development without poverty. Housing development has not kept pace with urban growth leading to severe overcrowding, congestion and slums. In Abuja the cost of living has forced residents to live in slums and shanty houses. According to Opoko and Oluwatayo (2014), Slums are areas of concentrated disadvantage. Life in slums is characterized by serious problems of environmental pollution, lack of access to the basic social services, poverty, deprivation, crime, violence, and general human insecurity and life threatening risks and diseases.

\section{Literature Review and the Theoretical Framework}

\subsection{Housing and Housing Poverty}

Housing is not only a necessity of life but also affect all aspects of our existence. Housing provides privacy and security against intrusions, both physical and emotional. It is the principal locus of our personal and family lives. Housing needs have been defined in general terms as: 
“... the extent to which the quantity and quality of existing accommodation falls short of that required to provide each household or person in the population, irrespective of ability to pay or of particular preferences, with accommodation of a specified minimum standard and above" (Ha, Seong-Kyu, 2004).

The question is what are the minimum standards that must be met? They should include adequate space and privacy; basic facilities and services such as sewer system, water, electricity etc; good structure and environment with adequate building material.

Housing poverty includes the basic problems of housing shortage, poor physical conditions and overcrowding; problems of accessibility to suitable dwellings; and problems of suitability of the dwelling stock in terms of tenure, type, size, location and other qualitative aspects of the dwelling and the neighborhood environment (Ha, Seong-Kyu, 2004).

In nations where housing is largely distributed through the market, people with lower incomes, less wealth or less access to credit (typically due to worse employment positions) will have fewer housing choices. They typically have less desirable or poorer housing conditions than others, including homelessness; will find it harder to enter or be more likely to leave home-ownership; and are more likely to be found in rented tenures (Tunstall et. al., 2013).

\subsection{The Concept and Nature of Poverty in Nigeria}

People can be said to be in poverty when they are deprived of income and other resources needed to obtain the conditions of life - the diets, material goods, amenities, standards and services - that enable them to play the roles, meet the obligations and participate in the relationships and customs of their society (UNDP, 2006). Poverty encompasses not only material deprivation (measured by income or consumption) but also by many other forms of deprivation in different aspects of life such as unemployment, ill health, lack of education, vulnerability, powerlessness, social exclusion and so on. Under the capability deprivation approach, an individual may be defined as poor if he or she lacks basic capabilities. This is when one has a disease or disability which prevents him from achieving some basic functions (UNDP, 2006). Poverty is a situation where the resources of individuals or families are inadequate to provide a socially acceptable standard of living. The German Government in 1992, described poor people as "those who are unable to lead a decent life. Poverty is also defied as not having enough to eat, a high rate of infant mortality, a low life expectancy, low educational opportunities, poor water, inadequate healthcare, unfit housing and lack of active participation in the decision making process (Yunusa, 2008)

According to World Bank (2000), poverty in absolute terms suggests insufficient or the total lack of basic necessities like food, housing, and medical care. It embraces the inadequacy of education and environmental services, consumer goods, recreational opportunities, neighborhood amenities, and transport facilities. In relative terms, people are poverty stricken when their income fall radically below the community average ( Olaniyan and Bankole, 2005). Poverty is not simply low or inadequate income but refers also to a lack of physical necessities and other assets. Often poverty is precipitated by a loss of assets. Poverty implies deprivation of human needs that are not met (Ha, Seong-Kyu, 2004).

That poverty is an all-pervasive phenomenon in Nigeria today is an incontrovertible and generally accepted fact. But that such pervasive poverty should exist in a country that is so well- endowed with important mineral, and other natural resources is not so well understood (Nwoke, 2001). The poverty in Nigeria is quite disturbing. Both the quantitative and qualitative measures attest to the growing incidence and depth of poverty in the country. The situation presents a paradox considering the vast human and physical resources with which the country is endowed. It is even more disturbing that, despite the large amount of human and material resources that have been devoted to poverty reduction by successive governments, no noticeable success has been achieved in the direction (Olaniyan and Bankole, 2005).

Nigeria ranked third among world's ten countries with extreme poor citizens. According to World Bank, Nigeria with about 170 million population falls among the countries with extreme poverty whose over $70 \%$ population live on $\$ 1.25$ (N200) or even less per day. Specifically, the report revealed that $7 \%$ of the 1.2 billion people living below poverty line in the world are Nigerians. Among the causes of the endemic poverty in Nigeria as stated by the World Bank report include harmful economic and political systems, national conflict and violence, human rights abuses, weak government effectiveness and efficiency, weak respect for rule of law, weak control of corruption, environmental conditions and changes, and population growth and changes. But we feel that none of them would account for acute poverty in Nigeria as that concerning weak control of corruption.

Every day, there are reports of indictments of Nigerians in government and leadership offices and positions for misappropriation of public funds. But there are no such reports of prompt arrest and prosecutions of these corrupt government functionaries by government. The few that are jailed and disgraced to serve as deterrence to others are soon after their jail terms accorded state pardons with fanfare. Rather than fight corruption by prosecuting indicted officials the government hound and harass people who dare to expose corruption in the country. So the root cause of high poverty in Nigeria is the high corruption among government officials and leaders, hence the solution will be found 
when government stands up against corruption in the country (Daily Independence, 2014). The allegation by Lamido Sanusi, the suspended Central Bank of Nigeria's Governor, that the Nigerian National Petroleum Corporation, the state owned oil corporation, has not remitted $\$ 20.8$ billion to the federal account over a period of nine months, is being treated with levity, while the same Nigeria National Petroleum Corporation (NNPC) unilaterally paid itself N620 billion as subsidy on kerosene (Punch, 2015).

\subsection{The Rural Urban Fringe - Defining the Relationship between Gwagwalada and Federal Capital City}

The concept of urban fringe was first used by T.L. Smith (1937) in connection with Louisiana. In that original presentation, the urban fringe was defined as "the built up area outside the corporate limits of the city." As currently being used, the rural-urban fringe applies to that zone on the outer borders of the city, between the area of complete urban and complete rural land uses. It is an intermediate zone that shares the characteristics of both. The zone is variously called the metropolitan fringe and rural urban fringe. The rural urban fringe is the product of the process of invasion. The rural urban fringe is defined as the zone of transition in the land use as well as social and demographic characteristics which lies between the continuously built up urban and suburban areas of the central city, on the one hand, and the rural hinterlands, on the other. It is characterized by an incomplete range and penetration of urban utility services; uncoordinated zoning or planning regulations; and extension beyond, although contiguous with the political boundary of the central city. Thus the rural urban fringe is the product of the very process of city growth. It has been argued that city does not grow outwards in well-defined, advancing rings of rapidly completed development. Rather, it extends haphazardly, making rapid advances at one point, and hardly moving at all at another. This process occasion the incoherent and interpenetrating transient land use patterns characteristic of the rural urban fringe (Onokerhoraye and Omuta, 1987). The foregoing expression of rural urban concept defines the relationship of city centre and Gwagwalada town of the FCT, Abuja. The nature of development in the FCT, Abuja is a development that can be described as the city centre being the urban and the rest Local Area Councils being the urban fringes. Developments have been so concentrated in the city centre that every other area in Abuja are hardly regarded as part of FCT but only merely defined as Abuja city hinterlands. Most parts of these various areas lack good roads, electricity, pipe borne water, park and recreational facilities; and in places where the facilities are available such as electricity and pipe borne water, they are never regular and accessible like they are in the city centre. This perhaps is the reason for the low house rent and why majority of the people who work in the City Centre wish to reside in them undermining their long distances from the city centre

\section{Study Area and Research Methodology}

The study area is Gwagwalada Town Abuja (Figure 2). Gwagwalada is the headquarters of Gwagwalada Area Council. Gwagwalada area council is located in the heart of FCT, Abuja, Nigeria. Its geographical coordinates are 8.56' 29" North, 7. 5' 31" East. Before the creation of Federal Capital Territory, Gwagwalada was under the Kwali District of the former Abuja Emirate. Gwagwalada area council was created on $15^{\text {th }}$ October, 1984. Its official population figure of 150,000 people has since becomes obsolete. The relocation of the seat of government from Lagos to Abuja in 1992 and the recent demolition of illegal structure within the Federal City Centre brought a massive influx of people into the area council being one of the fastest growing urban centers in the FCT. The population of the area has grown to over $1,000,000$ people. Subsistence agriculture is the main economic activity of the rural populace. Gwagwalada is also favourable for livestock production because of the abundant grazing land. It is strategically located and this makes it easily assessable to other bordering area councils such as kuje, Abaji, and Abuja Municipal. Gwagwalada is located at an elevation of 210 meters above sea level. It has an area of $1069.589 \mathrm{~km} 2$ with ten wards namely: Zuba, Dobi, Tunga Maje, Ibwa, Kutunkun, Ikwa, Paikon-Kore, Gwako, Quarters and Central.

The data for the study were derived from both primary and secondary sources. Primary data were derived from the administration of questionnaire. Stratified random sampling technique was used to administer the questionnaire to the respondents in the study area based on the income of respondents expressed as high, middle and low income areas. A total of six hundred (600) questionnaire were administered in the study area of which one hundred (100) questionnaire were administered in the high income area, two hundred (200) questionnaire were administered to middle income area while three hundred (300) questionnaire were administered to low income area. The data were analyzed using both descriptive and simple inferential statistics. 
Table 1. Data Presentation and Analysis

\begin{tabular}{|c|c|c|c|c|c|c|c|c|}
\hline \multicolumn{9}{|c|}{ (a.) Level of Income of the Respondents in the Study Area } \\
\hline Income of Respondents & \multicolumn{2}{|c|}{ High Income Area } & \multicolumn{2}{|c|}{ Middle income Area } & \multicolumn{2}{|c|}{ Low income Area } & \multicolumn{2}{|l|}{ Total } \\
\hline Income & Freq & $\%$ & Freq & $\%$ & Freq & $\%$ & Freq & $\%$ \\
\hline Below N18000 & 01 & 0.17 & 36 & 06 & 109 & 18.17 & 146 & 24.33 \\
\hline N18001-N30000 & 04 & 0.67 & 44 & 7.33 & 111 & 18.50 & 159 & 26.50 \\
\hline N30001-N60000 & 12 & 2.00 & 56 & 9.33 & 58 & 9.67 & 126 & 21.00 \\
\hline N60001-N100000 & 42 & 7.0 & 40 & 6.67 & 20 & 3.33 & 102 & 17 \\
\hline N100001 and above & 41 & 6.83 & 24 & 04 & 02 & 0.33 & 67 & 11.17 \\
\hline Total & 100 & 16.67 & 200 & 33.33 & 300 & 50 & 600 & 100 \\
\hline \multicolumn{9}{|c|}{ Respondents Length of Staying in the Study Area } \\
\hline Length of Staying & Freq & $\%$ & Freq & $\%$ & Freq & $\%$ & Freq & $\%$ \\
\hline Less than 5Year & 17 & 2.83 & 43 & 5.5 & 15 & 2.5 & 85 & 10.83 \\
\hline 6-10 Years & 22 & 3.67 & 49 & 8.17 & 63 & 10.50 & 154 & 22.34 \\
\hline 11-15 Years & 38 & 6.33 & 63 & 10.5 & 101 & 16.83 & 202 & 33.66 \\
\hline 16 Years and Above & 23 & 3.83 & 55 & 9.16 & 121 & 20.17 & 199 & 33.17 \\
\hline Total & 100 & 16.66 & 200 & 33.33 & 300 & 50 & 600 & 100 \\
\hline \multicolumn{9}{|c|}{ (c.) Respondents Reasons of Staying in the Study Area } \\
\hline Reasons of Staying & Freq & $\%$ & Freq & $\%$ & Freq & $\%$ & Freq & $\%$ \\
\hline Cheaper Rent & 52 & 8.66 & 119 & 18.17 & 216 & 36 & 377 & 62.83 \\
\hline $\begin{array}{l}\text { Staying with Relatives } \\
\text { and Kinsmen }\end{array}$ & 27 & 4.5 & 42 & 7.0 & 52 & 8.67 & 121 & 20.17 \\
\hline Closer to Work & 21 & 3.5 & 49 & 8.17 & 32 & 5.33 & 102 & 17 \\
\hline Total & 100 & 16.66 & 200 & 33.34 & 300 & 50 & 600 & 100 \\
\hline \multicolumn{9}{|c|}{$\begin{array}{ll}\text { (d.) } & \text { Household Size of the Respondents in The Study Area } \\
\end{array}$} \\
\hline $1-3$ & 20 & 3.33 & 45 & 7.5 & 18 & 3.0 & 83 & 13.83 \\
\hline $4-7$ & 42 & 7.00 & 67 & 11.17 & 59 & 9.83 & 168 & 28.00 \\
\hline $8-11$ & 27 & 4.5 & 53 & 8.83 & 97 & 16.17 & 177 & 29.50 \\
\hline 12and Above & 11 & 1.83 & 35 & 5.83 & 126 & 21.00 & 172 & 28.66 \\
\hline Total & 100 & 16.66 & 200 & 33.33 & 300 & 50 & 600 & 100 \\
\hline \multicolumn{9}{|c|}{ (e.) Housing Type of the Respondents in the study Area } \\
\hline Housing Types & Freq & $\%$ & Freq & $\%$ & Freq & $\%$ & Freq & $\%$ \\
\hline Rooming Apartment & 02 & 0.33 & 14 & 2.33 & 206 & 34.33 & 222 & 36.99 \\
\hline \multicolumn{9}{|l|}{ Apartment } \\
\hline Flat & 98 & 16.33 & 186 & 31.0 & 30 & 5.0 & 314 & 52.33 \\
\hline Duplex & - & - & - & - & - & - & - & - \\
\hline Traditional & - & - & - & - & 64 & 10.67 & 64 & 10.67 \\
\hline \multicolumn{9}{|l|}{ Compoumd } \\
\hline Total & & & 200 & 33.33 & 300 & 50 & 600 & 100 \\
\hline \multicolumn{9}{|c|}{$\begin{array}{ll}\text { (f.) Age of Building in the Study Area } \\
\end{array}$} \\
\hline Age of Building & Freq & $\%$ & Freq & $\%$ & Freq & $\%$ & Freq & $\%$ \\
\hline $0-10$ Years & 30 & 5.0 & 34 & 5.67 & 21 & 3.5 & 85 & 14.17 \\
\hline 11-20 Years & 27 & 4.5 & 48 & 8.00 & 47 & 7.83 & 122 & 20.33 \\
\hline 21-30 Years & 38 & 6.33 & 62 & 10.33 & 75 & 12.5 & 175 & 29.16 \\
\hline 31-40 Years & 03 & 0.5 & 30 & 5.0 & 96 & 16 & 129 & 21.5 \\
\hline 41 years and Above & 02 & 0.33 & 26 & 4.33 & 61 & 10.17 & 89 & 14.83 \\
\hline Total & 100 & 16.66 & 200 & 33.33 & 300 & 50 & 600 & 100 \\
\hline \multicolumn{9}{|c|}{$\begin{array}{ll}\text { (g.) } \quad \text { Condition of Building in the study Area } \\
\end{array}$} \\
\hline Condition of Building & Freq & $\%$ & Freq & $\%$ & Freq & $\%$ & Freq & $\%$ \\
\hline Poor & 23 & 3.83 & 67 & 11.17 & 155 & 25.83 & 245 & 40.83 \\
\hline Fair & 31 & 5.17 & 102 & 17 & 97 & 16.17 & 230 & 38.34 \\
\hline Good & 46 & 7.67 & 31 & 5.17 & 48 & 8.00 & 125 & 20.84 \\
\hline Total & 100 & 16.66 & 200 & 33.33 & 300 & 50 & 600 & 100 \\
\hline Condit & on of th & ronmen & Study & & & & & \\
\hline Poor & 21 & 3.5 & 64 & 10.67 & 162 & 27 & 247 & 41,17 \\
\hline Fair & 32 & 5.33 & 106 & 17.67 & 98 & 16.33 & 236 & 39.33 \\
\hline Good & 47 & 7.83 & 30 & 5.0 & 40 & 6.67 & 117 & 19,5 \\
\hline Total & 100 & 16.66 & 200 & 33.33 & 300 & 50 & 600 & 100 \\
\hline
\end{tabular}

Author's Field Survey, 2013

\section{Results and Discussion of Findings}

Table 1a. shows the level of income of the respondents in the study area. it reveals that majority of the people in the low income area earn below N18000 while in the middle and high income area, only 6\% and $0.17 \%$ earned below N18000 respectively. This reveals that poverty is more obvious in the low income earners' area than that in the high and middle 
income earners' area. This has negative effects on housing conditions and the entire standard of life of the people in the low income area.

The lengths of time respondents have stayed in the study area are presented in table $1 \mathrm{~b} .33 .66 \%$ of the people have spent between 11 and 15 years as residents in the study area. This is followed by $33.17 \%$ of the respondents who have been staying in the study area for over 16 years while $22.34 \%$ and $10.83 \%$ of the respondents have lived in the study area for less than 5 years and 6 to 10 years respectively. The study reveals that low income area has the highest percentage $(20.17 \%)$ of the respondents who have been staying in the study area for over 16 years followed by $16.83 \%$ of the respondents staying the study area between 11 and 15 years and followed by middle income area with $10.50 \%$ of the respondents and high income area with $6.33 \%$ of the respondents staying in the study area between 11 and 15 years. What this analysis portends is that the people in the low income area have not been able to change their accommodation because of poverty level as majority of the respondents are earners of low income. Thus what this has confirmed is that the type and condition and or location of housing are dependent or determined by the income level of the people in the study area.

On the respondents reasons for staying in the study area (table 1c), $62.83 \%$ of the respondents stay in the study area because of the reason that has to do with cheaper rent, followed by $20.17 \%$ staying with relatives and friends and only $17 \%$ for reason of close to work. The study shows that low income area has the highest percentage (36\%) staying in the study area because the rent are cheap compared to high and middle income areas. This reveals that people can due to poverty and the fact that they are low income earners overlook closeness to work and have their residences in area far from the cities or place of work as far as such areas (suburbs) are able to offer cheaper accommodation. The analysis also shows that majority of the people staying in the high income area are there because the area is closer to their place of work. This group of people is not minding the cost of rent but prefer these places because of its convenience. In the case of the low income area, a high percentage (36\%) of the respondents are staying there because the rents are cheap. This is why there is overcrowding and much pressure on the facilities in the low income area which cosequently have negative impact on the housing condition.

On the household size of the respondents (table 1d), while a high percentage of $29.50 \%$ of the respondents have household size of 9-12 followed by another high percentage (28.66\%) of the respondents having more than 12 people as household about $28 \%$ and $13.83 \%$ having $4-7$ and 1-3 households respectively. The analysis also reveals that low income area has the highest percentage of household size. As shown in the table, $21 \%$ of respondents had more than 12 as household size while in the high income area a percentage of 7\% of the respondents had 4-7 household size. This reveals that low income area has very high occupancy ratio and this can have a lot of negative impact on the housing condition and the living environment. High occupancy ratio manifest overcrowding or congestion and one of the consequences of this is increased pressure on the housing facilities. Occupancy rate is usually given in number of person per habitable room. It expresses the number of person within a building. It is a rough measure of the adequacy of accommodation available as it gives indication overcrowding and under utilization.

In the case of the analysis of housing types of respondents (table 1e), the study shows that majority of the respondents in the low income area are living in rooming and single room apartment. The analysis shows that a high percentage $(34.33 \%)$ of the respondents are living in a rooming and single room apartment while in the high and middle income area majority are living in flat because their level of income is high and could be afforded by them.

On the age of buildings (table 1f), 29.16\% of the respondents are living in buildings between the age of 21 and 30 years, followed by $21.5 \%$ living in buildings of 31-40 years of age, 20.33\% living in houses of 11-20 years of age, $14.83 \%$ and $14.17 \%$ living in buildings of above 41 and $0-10$ years of age respectively. The analysis shows that in the low income area, the highest percentage (16\%) of the respondents live in buildings of 31-40 years of age and followed by $12.5 \%$ of the respondents living in buildings of 21-30 years of age.

In the case of condition of buildings in the study area (table 1g), $40.83 \%$ of the respondents are living in poor condition of housing and followed by $38.34 \%$ living in houses said to be fair. The analysis shows that buildings in the low income area are poor as stated by $25.83 \%$ of the respondents. What table $1 \mathrm{f}$ and $\mathrm{g}$ have shown is a further revelation of the level poverty in the low income area considering the age of buildings the respondents are living. Through observation, most of the buildings are in a state of deterioration and dilapidation. Most of the structures are in need of major repair while others are with major defects. Some of the structures are unsafe for human habitation.

\section{The implication of the Findings}

The earnings of the low income group show that they will always find it difficult to have effective means of having a good standard of living and good housing condition. Since majority of them are self-employed and their income are very low to meet their daily needs, they are not able to able to change their accommodation from their squalor to better housing and environmental condition. Poverty breeds high occupancy rate. The study has shown that high occupancy 
rate causes congestion and overcrowding. What this portends is that there will be high rate of waste generation which can lead to outbreak of diseases. Another dimension of the problems include the fact that many of the respondents are not able to live close to their work places as a result of their low earnings because they have to live in places where they can have access to cheap accommodation. The implication of this is that the people spend a lot of their money on transportation travelling to their work places, a lot of man hours are wasted every day going to work because of the long distance to be covered, and the risk of travelling. Gwagwalada is a town that is about $65 \mathrm{~km}$ away from the city centre where majority of the respondents travel to every day for work. This shows that the respondents spend a lot of money, time and energy including taking risks to get to work every day. If poverty is not addressed, growth of slums and informal settlements will continue to spread in Gwagwalada urban area and become a major feature of Abuja urban landscape. Growths of slums and informal settlement have evolved in Gwagwalada in response to government inability to provide adequate housing for the teeming population.

\section{Conclusion and Recommendations}

This paper presented an analysis of the impact of poverty on housing condition in Nigeria with particular emphasis on Gwagwalada Town in the Federal Capital Territory Abuja. The analysis indicated that poverty is widespread in the study area and that the income level of the people determines the condition of housing and standard of living of the people. This study therefore suggests the need for a conscious effort to address the housing poverty in our environment by increasing the provision of adequate housing to individuals. Government should institute a planning and regulatory framework responsible for establishing new towns and opening up new areas serviced with relevant infrastructure in order to tackle the growth of informal settlement. Findings from the study also place a considerable emphasis on the need to develop a sustainable supply of finance to fund low cost housing. Hence, there is need to recognize the National Housing Fund (NHF), to make it more responsive to the needs of the people so that the people (i.e. low income households) can have access to Mortgage. Banks and Financial Institutions should be mandated and monitored in setting aside a percentage of their loanable funds to low income households. It should also be considered that any increase in the income of the people in the urban areas would inevitably lead to a significant decrease in housing poverty.

\section{References}

Aluko, A. M. O. (2001). Strategies for Poverty Reduction in Nigeria. In Research and Policy Directios on Poverty in Nigeria, edited by Afonja, S.; Adelekan, D.; Soetan, F.; Alimi, T.; and Ayanwale, B. (Eds.). Ile Ife: Anchor Print Ltd.

Daily Independent (2014). World Bank Report on Poverty in Nigeria. www.dailyindependentnig.com.

Fukuda-Parr, S. (2006). The Human poverty Index: A Multidimensional Measure. In What is Poverty? Concepts and Measures, A Publication of International Poverty Centre, Poverty in Focus, United Nations Development Programme (UNDP)

Nwoke, C. N. (2001). The Paradox of Poverty in Nigeria. In Research and Policy Directions on Poverty in Nigeria, edited by Afonja, S., Adelekan, D., Soetan, F., Alimi, T., \& Ayanwale, B., 116-126, Ile Ife: Anchor Print Ltd.

Olanrewaju, O., \& Bankole, A. S. (2005). Human Capital, Capabilities and Poverty in Rural Nigeria. Ibadan Journal of the Social Sciences, 3(2), 13-27.

Onokerhoraye, A. G., \& Omuta, G. E. D. (1987). Urban Systems and Planning: the Geography and Planning Series of Study Notes. Benin City: Universty of Benin

Opoko A. P., \& OLuwatayo, A. (2014). Trends in Urbanization: Implication for Planning and Low Income Housing Delivery in Lagos Nigeria. Architecture Research, 4(1A), 15-26.

Punch (2014). World Bank on Extreme poverty in Nigeria. www.punchng.com/editorials/

Seong-Kyu, H. (2004). Housing Poverty and the Role of Urban Governance in Korea. Environment and Urbanization, 16(1), 139-154

Tunstall, R., Bevan, M., Bradshaw J., Croucher, K., Duffy, S., Hunter, C., Jones, A., Rugg, J., Wallace, A., \& Wilcox, S. (2013) The Links between Housing and Poverty: An Evidence Review. Joseph Rowntree Foundation Report, York: Joseph Rowntree Foundation.

UNDP (2006). Poverty in Focus. International Poverty Centre, Brazil: United Nations Development Programme

World Bank (1999). Understanding and Responding to Poverty. www.worldbank.org/poverty/mission/...htm. 


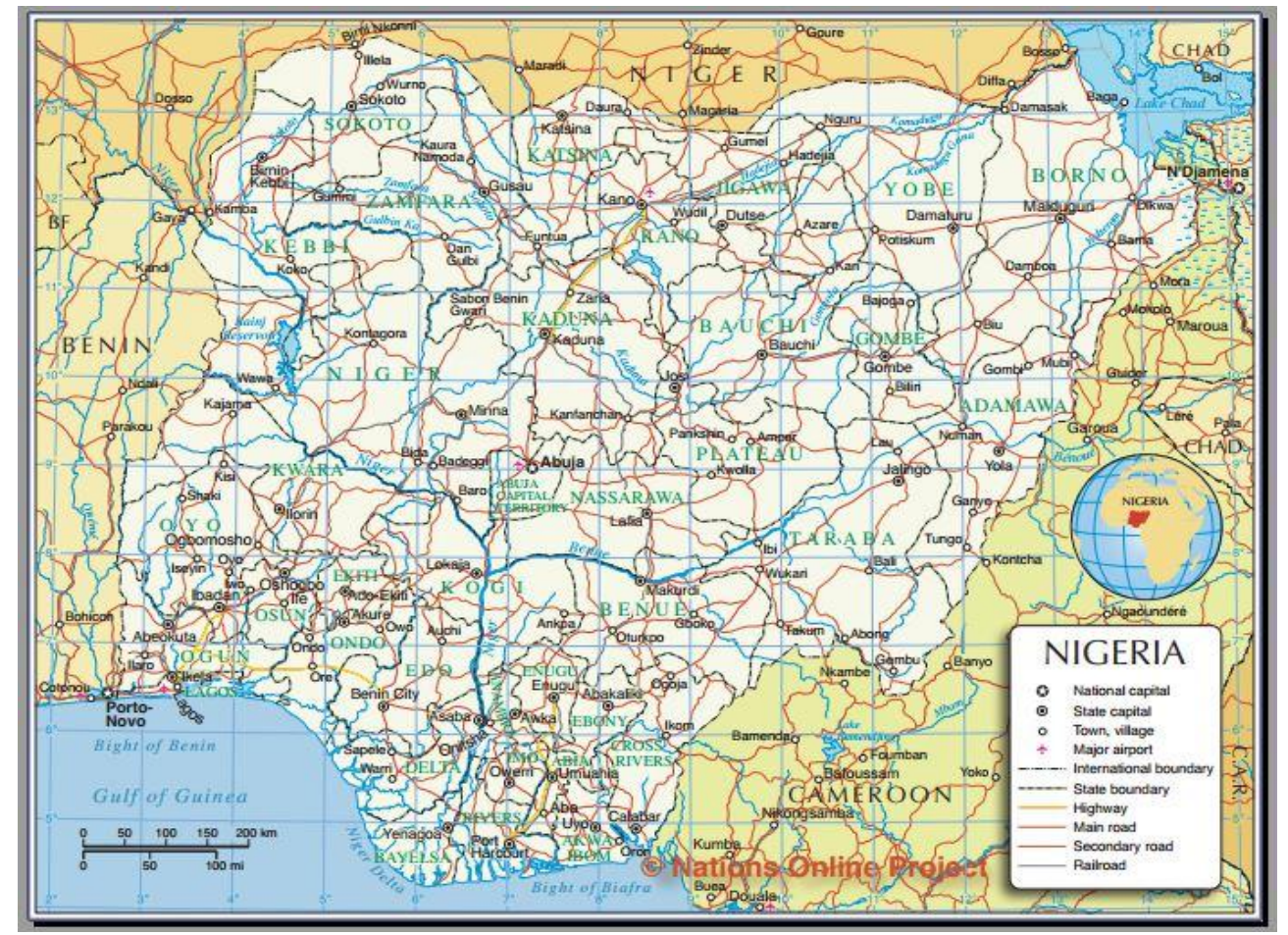

Figure 1. Map of Nigeria

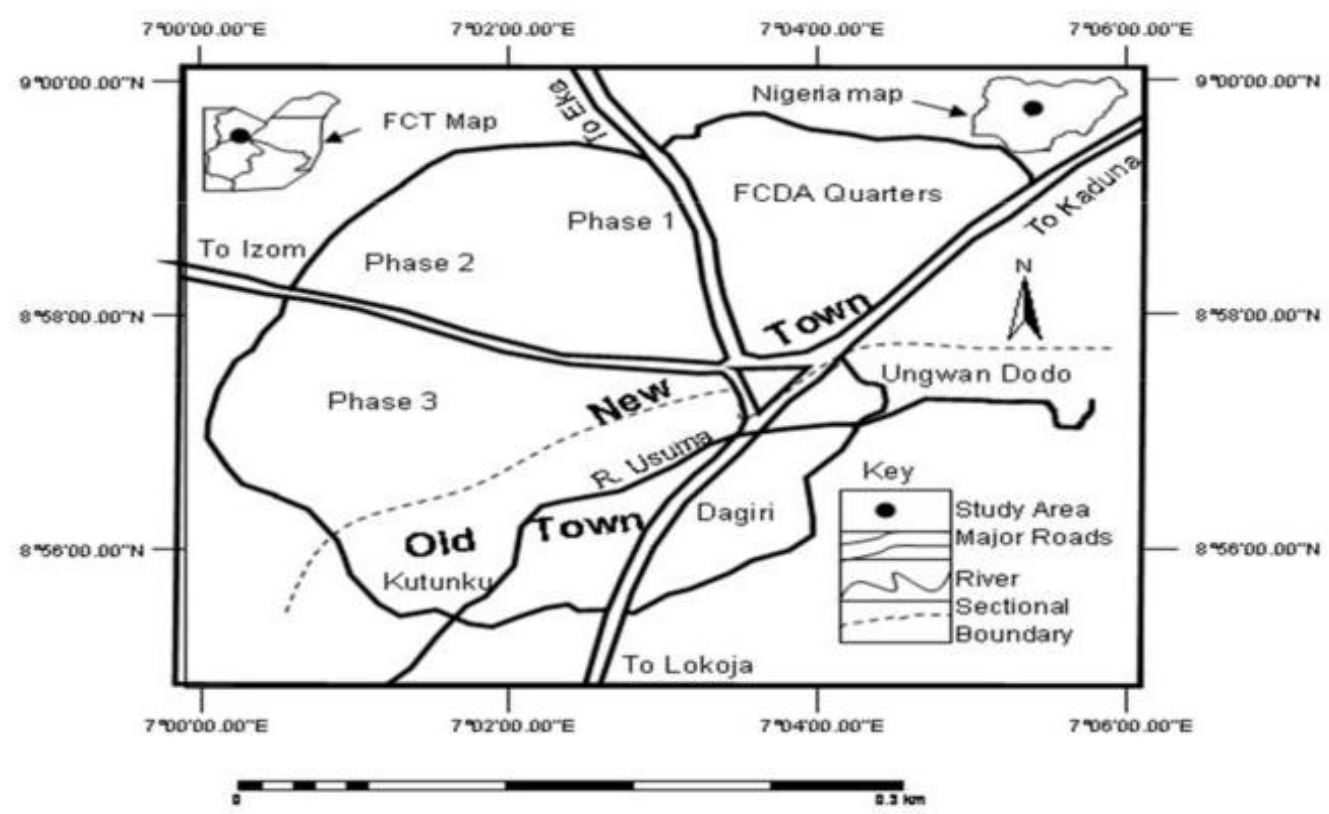

Fig. 1 Gwagwalada Town

Figure 2. Map of Gwagwalada Town, Abuja.

\section{$(\mathrm{cc}) \mathrm{EY}$}

This work is licensed under a Creative Commons Attribution 3.0 License. 